\title{
MUSIC HALL, JIGS AND STRIPPERS: ENGLISH LOW-BROW MUSIC IN FRENGH NINETEENTH-GENTURY TRAVEL WRITING
}

\author{
HANNAH SCOTT
}

\begin{abstract}
It is a commonplace to remark that nineteenth-century England was a land without music. Yet French travel writers in the fin de siècle remark again and again on their astonishing, low-brow musical encounters in the nation's capital. The present article examines such experiences in the writing of Jules Vallès and Hector France, as they turn their steps away from the refinement of Covent Garden to seek out more esoteric musical experiences in the music halls, tawdry bars, minor theatres and strip joints of London. These texts present an intriguing and ambivalent textual form to the reader. Though being based on - and structured as - travel anecdotes, they no less insistently reach beyond the anecdotal experience to extrapolate overarching conclusions about the English and their character relative to France. Yet in doing so, their texts reveal inconsistencies and contradictions as they try to reconcile these strange musical experiences with the stereotypes of Englishness that had solidified over the generations; these alien musical experiences resist conceptualization and challenge the tropes that had for so long underwritten French ideas of the English Other.
\end{abstract}

Keywords: travel writing; fin de siècle; French; music hall; London; Jules Vallès; Max O'Rell; Hector France; jig; national character

IT IS A COMMONPLACE to remark that nineteenth-century England was a land without musical talent, without genius in composition or practice. The influential music theorist François-Joseph Fétis remarked in I833 that 'l'opinion souvent manifestée par les écrivains du continent place les Anglais au degré le plus bas de l'échelle des facultés musicales'. 'The Comte L. Lafond, on hearing a group of young people singing psalms in the street, noted that they sang with 'ce parfait mépris de toute règle musicale qui distingue le peuple britannique', and Edmond de Goncourt painted, as the epitome of English womanhood, Lord Annandale's cousin in La Faustin who 'sans repos, sans relâche, avec un entêtement de femelle britannique, [...] jouait du piano seize heures par jour, ne possédant pas la plus petite aptitude musicale et la moindre "oreille". 2 With the prevalence of such an attitude, it is easy to assume that nineteenth-century French writers and journalists would dedicate little space to 
musical culture in their diaries and travelogues from England. Certainly, as far as art-music composers are concerned, the French demonstrate minimal awareness of English practitioners of any calibre; Edward Elgar and Frederick Delius are conspicuously absent from contemporaneous studies which claim to encapsulate the musical world of the day, such as Adolphe Jullien's Musiciens d'aujourd'hui (I892), Romain Rolland's book of the same title from I9o8, and Alfred Bruneau's Musiques d'hier et de demain (I900). ${ }^{3}$ Handel alone is occasionally cast as a composer worthy of attention (Handel is generally treated as English rather than German, despite his birthplace). However, his elevated degree of talent is used as evidence that he transcends his English milieu to attain instead the status of a universal artist, as Shakespeare had done in the dramatic arts - the journalist Fourcaud goes so far as to reassure his readers in the publicity for a performance (in French) of Handel's Messiah at the I889 World Fair that Handel's musical genius 'n'a rien d'anglais'.

When it comes to music, then, England is surely the antithesis of France, the nation of Berlioz, Saint-Saëns, Gounod, D'Indy, Massenet and Boieldieu; as Jann Pasler has noted, both Renan and Taine saw a love of the beautiful and the sublime as distinctively French traits, French musicians were proud of their superiority in musical lyricism, and the ideas of the French musical elite gradually became an internationally-recognized marker of good taste. ${ }^{5}$ With this in mind, in music as in so many other ways in their long shared history, England therefore provided the French observer with an inverted mirror image of what it meant to be French and what was great about France. ${ }^{6}$ Jane Fulcher has observed that in Third Republican France, 'music became a symbol within an internal struggle over conflicting notions of identity and the legitimate state', leading to deeply embattled ideological and political conflicts between factions in France. ${ }^{7}$ By turning their gaze across the Channel, though maintaining the same subject of study, many writers seem to seek out a musical culture external to France that could be identified by all as un-French and thus help to unite the many conflicted factions behind a common idea of the Other.

In many ways, this impulse to use music to establish hierarchies of Self and Other and provide shared reference points for the French correlates with the treatment of music in travel writing more widely. Ruth Rosenberg has examined music in the travel literature of the early nineteenth century, observing how musical encounters are used by Chateaubriand and de Tocqueville to reflect upon domestic French and personal subjective issues. ${ }^{8}$ Such usage would gain new currency when contemporary anthropological and sociological thought proposed a correlation between the aesthetics of Western art music and the advancement of evolution - such as the narrative traced by Darwin in the Descent of Man from the tiniest buzzing insect, to the calling of gibbons, to the rhythmic 'primitive' music of Hottentots and Negroes, and culminating in the Western art-music tradition. ${ }^{9}$ Pamela Potter has usefully observed in her study of European colonial thought on music that 'interest in music as a manifestation of racial differences grew [...] as European explorers visited Africa and Asia and recorded their observations,' and Annegret Fauser has traced the impact of such interest across the international musical spectacles at Paris's i889 World Fair. ${ }^{10}$ 
However, far from being restricted to distant, non-white races, a similar standpoint was used to examine other European nations via their musical cultures in the nineteenth century, including England, for as Pasler remarks, 'the instincts of a race were thought to affect the artistic progress of a nation'. ${ }^{11}$ Music was therefore taken up both to supply the material for genuine anthropological study and to justify preconceptions or bolster politically-motivated assertions about the relative worth of England and France, much as it was vis-à-vis the Orient: if French art music was seen as the marker par excellence of civilization and good taste, then to underline (and double-underline) its indigenous absence from England served as a powerful counter-argument to those who lauded England as a model for progress, education and social organization. ${ }^{12}$ In the heat of colonial rivalry with Britain, and faced with the need to shore up national pride in the wake of 1870 to I87I more generally, many nationalistic writers exhibit a deep-seated need to prove the inferiority of this rival nation - and given England's apparent dearth of musical talent, a focus on music provides an ideal vehicle for establishing this hierarchy.

However, unlike colonial or non-white nations over which it was simple to establish a position of power and superiority within the normal auspices of nineteenthcentury ideologies, travel writers on England had to go to some rhetorical lengths to craft a selective vision of English musical culture in order to maintain this clear-cut binarism - particularly since contact between the two nations was significantly more frequent. Although the English were thought to have an apparently limited compositional culture (this assumption, already, discounts the rich nineteenth-century tradition of hymnal composition), the nation's enthusiasm for and appreciation of Western art music was everywhere in evidence. Indeed, the apparent astonishment of journalists at the extent of this enthusiasm suggests that its reach was considerably greater than that seen in the wider French population. The eyes of French music journalists were rivetted for three to four months every year upon London for the duration of the Season. To take a sample case from one of the leading musical papers, Le Ménéstrel, the special correspondent H. Moreno took up residence in London in 1872 at the very start of the Season, the better to report on every minute detail as the international opera stars arrived, as the concert bills for the Season were announced, and as the crème of musical events took place right up until the end of June. ${ }^{13}$ As the Season rose to its climax, Moreno comments that the English addiction to music was 'à n'y pas croire', and the demand for quality song and music flooded beyond West End theatres and across the entire city, 'dans tous les quartiers de Londres, sur tous les théâtres, dans toutes les salles de concerts et en mille autres lieux transformés en salons à musique pour satisfaire l'insatiable appétit des innombrables dilettanti anglais'. ${ }^{14}$

And yet in spite of their full awareness of a flourishing art-music performance culture in England and the near-fanaticism of English audiences, it is a trope of French travel writing on England to demonstrate the dearth of 'good' (that is, highbrow, art) music by emphasizing the presence of 'bad' (that is, middle- and low-brow, popular) music. It is the choice to focus on this musical sphere that is explored in the present article. It examines the representations of non-art music in London by way 
of two travel narratives: an evening at the music hall detailed by the French exile Jules Vallès in his La Rue à Londres (I884, a compilation of articles written in I876 to I877), and several visits to the dive bars and strip joints of East London by the travel writer Hector France. These are among the most emphatically anti-English narratives of their kind, but their treatment of music is by no means anomalous: rather, they present a condensed and somewhat hyperbolized version of the numerous negative tropes widely associated with English music at this point in time. Vallès and France dismiss the refinements of Covent Garden to focus instead on the more 'typical' musical experiences in the streets, bars and minor theatres of the capital city, and in so doing they seek to impress upon the reader, to reprise Pasler's terms, the (baleful) instincts of the English race through the (equally baleful) artistic progress of the English nation. Instead of highbrow and lowbrow signifying class differences within France, here they are presented to the French readership as revelatory of differences in national character and worth. ${ }^{15}$

These French texts on lower-brow musical encounters have escaped the attention of scholarship to date, but they present an intriguing and ambivalent form to the reader. To some extent, these noisy tales of appalling English music are simply the product of a need for writers and their publishers to grasp the reader's interest especially since a steady stream of travel narratives on England had been flowing out of Parisian publishing houses since the eighteenth century and areas for novelty were in short supply. However, underneath the initial aesthetic condemnations and jingoistic bluster, there also lie clear signs that this discordant English music presents something more complicated, peculiar and unsettling, which challenges the efforts in these texts to mould the idea of England into a simplified, common Other for the French. These noisy tunes cannot be conceptualized using familiar critical modes of analysis, and thus they reveal the limitations of such familiar viewpoints; issues of class, modernity, aesthetics, concepts of national character and superficial musical understanding cast doubt over simplistic assertions, both when interpreting the music itself, and when using music to conceptualize the culture of France's neighbour and rival more widely.

\section{At the music hall}

Nearly every French visitor to London has something to say on the popular genre of music hall. It is not the leading stars who draw their attention, such as the internationally celebrated Queen of the Music Hall Marie Lloyd in the I880s and I8gos, and they care little for the more glamorous music halls of the West End; instead, writers present an image of a run-of-the-mill entertainment, favoured by average middle- and lower-class Englishmen and women. Indeed, the audience are as much the focus of these commentaries as the acts themselves. As an organically English entertainment (unlike European opera), the audience's behaviours must surely provide incontrovertible evidence of English national character. Nonetheless, in making this assumption, it is not long before difficulties arise. It is clear that French writers can identify the social class of people attending the music halls: Jules Vallès notices that 
John Bull, his family, miners and factory workers are the target audience for these establishments, and the celebrity travel writer and lecturer Max O'Rell [pseud. Léon Paul Blouet] recognizes the predominance of le cockney (his short-hand for all of London's working classes) during his theatrical experiences. ${ }^{16}$ Yet they gloss over the fact that it is deeply problematic to take this section of society as representative of 'Englishness' as a whole; they ignore the specificity of lifestyle, community structures, exposure to outside cultures, and even genetic heritages entailed in the lower-class audiences of this diverse, modern, industrial city. Further, almost no consideration is given to the implications that such class-specific differences might have for the performance styles and the signification of the content at the music hall. Certainly, neither Vallès nor France would have been guilty of the same oversights about Paris; a writer declaring that the Parisian workers were representative of the Parisian elites, or that they were representative of the lower classes of Gascony or Brittany, would either have caused a scandal or have been laughed out of the bookshops.

It is particularly surprising to find issues of class disregarded by Jules Vallès, given his collaboration with the workers in the Commune of 187 I and his record of outspoken criticism against the capitalist culture of the Second Empire. His depiction of music hall in England is among the most extensive in any French account at the time, notably in the instalment entitled 'Le Soir' from a series of articles published by L'Événement in 1876 to 1877 during his exile, and then later in book form as La Rue à Londres in I884. 'Le Soir' details the various entertainments available in London, briskly passing over theatre and art music, teasing through the poor quality of the directing, the lack of talent on stage, the absence of elegance or grace, and the indifferent theatrical journalism, before arriving at the proliferation of music-hall theatres and their immense size (quantity at the expense, he implies, of quality). Here Vallès lingers, and his use of highly affective, derogatory descriptors from the outset of the instalment demonstrates that there is no intention here of simply providing a detached depiction of a curious cultural phenomenon.

Instead, what Vallès hears and sees (and, it is reasonable to assume from the hyperbolic tone, paints with a degree of artistic licence) is employed to reinforce pre-existing negative stereotypes of the English and reaffirm his own and France's superiority rather than to seek out new insights. The first key stereotype, in the opening lines of the section on the music hall, revolves around the Chairman: Vallès asserts that he is not a mere host or announcer, but is like an auctioneer proposing the acts as objects for sale. This is to be expected, as the French are familiar with the cliché of the English as a nation of shopkeepers and merchants without human feeling - in a circular gesture Vallès uses the stereotype to explain the behaviour of the Chairman, and uses the Chairman to prove the veracity of the stereotype. In case the reader has failed to recognize that the Chairman is not depicted here as an anomaly but as the manifestation of the flaws of the whole nation, Vallès clarifies explicitly that:

ce chairman [...] c'est bien l'Angleterre, - l'Angleterre de la respectability et du business, qui, frac au dos, marteau au poing, - appelle les artistes comme les recrues, et ne permet pas 
que les belles filles restent sur la scène pour rien. [...] Chanté! Dansé! Adjugé! - À un autre! Comme je te reconnais d'un coup, ô brutale Angleterre! (pp. 36-37)

Following the Chairman, each character in turn is rooted in a familiar stereotype with a similar degree of insistence; there is the audience (who are fuelled by the capitalized 'Orgueil anglais', p. 38), the jig dancer ('cette marionnette', p. 37), and the female performer ('[qui] a l'air d'un garçon en fille', p. 43). Of course, some allowance must be made here for Vallès's unenviable position as an exile in London and for the destitution he suffered during this time; his struggle to make an adequate living and London society's treatment of him as just another faceless immigré would naturally have added humiliation to his intense solitude, caused bitterness, and given him reason to want to take a position of linguistic agency to counteract his social powerlessness. However, the target of his anger here seems radically misdirected; first, even when the capitalists of London treated him brusquely, they are not the class of people he encounters at the music hall - indeed, it is quite probable that many other music-hall goers have suffered similar or even worse treatment at the same hands; and secondly, the degree of violence and hatred expressed in his depiction of the disadvantaged and destitute of England is positively vindictive. In the first instalment of La Rue, Vallès had already described with overwhelming disgust the filth of impoverished, brutalized women eking out a living as flower-sellers and the half-starved children of slum housing (p. 4) - it is a tone of scorn not tragedy that dominates here - and he goes on to complain callously that London's 'viande à plaisir' offend him because they wear rags and because they have the unattractive habit of complaining that they are hungry (pp. 54, 62). His own unstable and uncomfortable situation seems, paradoxically, to translate a nostalgic sympathy for the French peuple into a hostility against the English populace, shifting the focus of his ideologies from one of class to one of nationalism. This experience of hardship that he shares with the lower classes of England, rather than deepening his sense of class brotherhood, instead leads him to vituperate against England as a whole.

There are two acts at the music hall that Vallès describes in detail and that are particularly striking. First is his scathing critique of the black-face minstrel act. ${ }^{17}$ The soundscape he transmits is described as merely the sum of a number of disagreeable sounds: 'l'orchestre grince [...] qu'on est dans un pays de spleen et de cauchemar, plein de gens qui sont saouls de religion ou de gin', and the music is 'criard comme un public-house'; the banjo tune played by Kaffir à l'œil blanc (White-Eyed Kaffir the stage name of G. H. Chirgwin) is a 'musique monotone et nue' (p. 4I); the typical female singer has a voice 'trempée de vinaigre, accordée sur un miaulement' or otherwise '[elle] vomit des notes graves, aussi grosses que celles lâchées par les boulangers' (p. 44); and Vallès draws from all this a conclusion about the whole nation, that 'avant d'être un peuple d'artistes, ils sont une nation de boxeurs' (p. 45). Vallès dismisses the music as mere noxious sound, foregrounding a lexical field associated with noise, industry and aggression; after the 'mouvements de piston' of the jig dancers and the 'cercle implacable de la mécanique anglaise' (p. 37) slightly earlier in the same chapter, now the accompanying orchestra plays 'comme les coups 
de sifflet [qui] accompagnent le départ d'un train' and the expression vibrating along the violin strings is 'l'électricité de la mélancolie comme sur le fil des télégraphes' (p. 4I). This draws a direct parallel between one particular musical experience and his sweeping assessment of the population who mill constantly along London streets, moving like 'des pistons de machine, ils passent comme des courroies se mêlent, comme les trains se croisent. [...] Allez, le piston!' (pp. I-2; italics in original text).

If we take Vallès at his word, by all the standards of 'good' musical taste, this music is demonstrably 'bad'. Yet the audience's incongruously positive reaction to these terrible, nightmarish noises hints that there is something here which Vallès fails to understand - particularly given the apparent sobriety of the audience (this is one of the few occasions Vallès does not insist on the inebriation of the English). Without being aware of it, Vallès has recorded here the aural aesthetics that would soon be championed by modernism on both sides of the Channel. Music comes to reflect the sounds of the city, the mechanical and repetitive aspects of industry to which the workers are subjected in their daily occupations, and it speaks of the struggles of their existence. ${ }^{18}$ Through the veil of Vallès's aesthetic distaste, we catch a glimpse within music hall of an art form for the modern world and for the proletariat, encapsulated within what the arch-anglophobe Félix Narjoux rejected as 'un spectacle commun, qui n'est pas fait pour plaire à des esprits raffinés et délicats'. ${ }^{19}$ Narjoux is, though not for the reasons he imagines, correct; these performances are not made for the pleasure of the refined elites, but are moulded by and for the labouring population of the fin de siècle's industrialized, alienating urban environment - and as such music hall is that population's entertainment of choice.

The lower strata of society were not without affordable opportunities to hear more 'refined' music if they so wished, albeit not necessarily performed by the most successful or highly-trained musicians: the novelist and traveller Marie Anne de Bovet remarks that even in deepest rural Ireland touring companies passed through country towns with selections from Gounod's Faust and Bizet's Carmen. ${ }^{20}$ Rather, the lower classes actively choose the musical modes of entertainment and expression associated with the music hall. This discordant, shrill music seems to speak eloquently to the audience, and in reaction to different pieces of music which sound to Vallès to be of equally poor quality, they manifest diverse, active, physical responses. They do not, as Bertolt Brecht would later say of art music, allow the sounds and their aesthetic values to wash over them, being 'transported into a peculiar state of intoxication, wholly passive, self-absorbed and, according to all appearances, doped', ${ }^{21}$ but rather they are galvanized into enthusiasm by jigs and are nearly brought to tears by White-Eyed Kaffir's banjo music. Indeed, the very shape of the banjo seems to be a parody of classical tropes, being neither violin, nor cello, nor classical guitar, yet its form, the physics of its acoustics and its player's postures and gestures all call to mind and parody its high-culture counterparts. Instead of the feminine curves of the violin or cello (which would later be played upon by Man Ray in 'Ingres's Violin'), it presents the rounded pot-belly of the clown. No matter how forcefully Vallès argues that the entire audience and thus nation lack the esprit for either aesthetic judgement, proper human emotion or distinction of character, the intense 
pleasures expressed by this class-specific audience imply that such music should not in fact be interpreted according to questions of national character, but of engaged, deliberate lower-class counterculture.

Vallès ascribes the popularity of black-face minstrels to an inherent English thirst for asserting power. The English audience member:

se prend, pendant un quart d'heure, pour un planteur ou un commandeur de par-delà l'Océan, qui a le droit de faire sauter et gémir les esclaves. [...] C'est comme s'il régnait pour un moment sur une des possessions au-dessus desquelles flotte l'Union Fack et où des milliers de gens de couleur s'inclinent devant les favoris roux d'une centaine de marins anglais. (pp. 38-39)

British (and French) colonialism certainly did entail numerous episodes of inexcusable cruelty, but for the vast majority of the John Bulls and the 'gens de mines et d'usines' in this music-hall audience, the oppression of colonized subjects is something with which they were complicit only at several removes, for example as shop keepers selling exotic goods or dockworkers eking a precarious poverty-line existence from unloading cargo ships. Most of the lower- and working-class men in the theatre had only just been granted the vote (in the I867 Reform Act), the women would have to wait several decades longer, and they may well all have had only a general sense of what colonialism meant in practice - especially if they were illiterate, since compulsory primary education was introduced only in I880. Michael Pickering has remarked that:

minstrelsy was just as much about English social relations as it was about a scantily known Afro-American populace. What was being symbolically worked out in minstrelsy, at a metalevel of commentary, were questions about the status of white Victorian society. ${ }^{22}$

So in this context, where is the slave in the room? Far from identifying with the masters, whip in hand, much of the audience at these neighbourhood music halls would themselves have been wage slaves to Capitalism: enslavement was in fact a longstanding metaphor in nineteenth-century literature for the suffering of the working classes, ${ }^{23}$ and as Engels explained, "the slave is sold once and for all; the proletarian must sell himself daily and hourly. [...] The individual proletarian [is] property as it were of the entire bourgeois class which buys his labour only when someone has need of it.' ${ }^{24}$ Thus, when Vallès represents the audience being moved nearly to tears by the 'slave' music played by White-Eyed Kaffir, it suggests that far from identifying with the slave driver, they actually identify with the figure of the slave; they find in his music a means of vicariously expressing their own oppressed lot in society. The socially disadvantaged see a photographic negative of themselves being brought to life, they hear in his aesthetically marginal music the sound of their own social marginality, and they find therein a distraction from and coping strategy for their precarious social existence.

Vallès seems insensitive to this. He will, however, represent one act in overwhelmingly positive terms. A singer emerges from behind the audience, Vallès tells us, dragging his foot, decked in rags and smeared with dirt, and proceeds to sing 'd'une 
voix d'écrasé $[\ldots]$ des mots qui sont une plainte d'abord, mais qui, peu à peu, deviennent une raillerie féroce et douloureuse' (p. 39). As the song goes on, this beggar character lambasts the socio-political system in a satirical tirade that attacks the glory of Britain, the supposed generosity of the rich, the virtue of the queen, the integrity of Gladstone and Disraeli, and the persistence of poverty and hunger with an 'ironie sanglante' and a 'menace voilée!' (p. 39) - the likes of which would be impossible in France until rgo6 due to the enduring 'censure préventative [qui] condamne le café-concert à des rengaines qui vous feraient pleurer' (p. 4I). On this occasion, faced with such evident socio-political protest, Vallès does recognize a truly proletarian voice and is overjoyed at finding that such liberty of expression is possible. The forces of order allow it (no policemen arrest the singer), the audience do not protest that their sacred cows are being denigrated (indeed, they seem to be in consensus with his critical views), and all of this despite the fact that the British government, like the French, was actively aware of the political utility of music as a propaganda tool. ${ }^{25}$ Like the figure of the slave, the song of the beggar seems to accord with the audience's social disenfranchisement and to provide them with both a sense of class identity and a means of expressing their disadvantaged lot. Yet even though there is such a clear correlation between the deliberately jarring style of singing and the jarring political message, between the musical dynamics (that is, sound volume) and the strained social dynamics indicated in the lyrics, still Vallès does not consider looking for similar analogies in the other acts at the music hall - nor, indeed, does he consider extrapolating from this one act to inform his understanding of Englishness more widely. So ingrained is his belief in 'Orgueil anglais', and so firmly does he consider the English lower classes to be cowardly and fawning, that rather than being able to make objective observations he is blind - or more accurately, deaf - to the signification of what he hears. ${ }^{26}$

This selective hearing inevitably introduces contradictions into his text, and Vallès's preconceptions are confronted repeatedly by the complexities of reality. Such a confrontation often poses problems for travel writers (this has been widely discussed by scholarship on Oriental travels ${ }^{27}$ ), but rare are the absolute selfcontradictions that follow here. Quite contrary to his preceding remarks upon the Chairman as the embodiment of Englishness, Vallès now claims that the beggar character represents the 'génie de l'Angleterre' (p. 4I), even though the two characters - one oppressive, conservative and inhuman; one liberated, politically engaged and intensely human - manifest sets of mutually exclusive traits. He does not address this flagrant contradiction, but simply leaves readers to confront the tension themselves. This may be read alongside one unique moment of clarity in the previous instalment of La Rue à Londres when Vallès cries, seemingly in despair, 'quelle ville!. . . toute pleine de contradictions énormes, amas de confusion! [...] Des silences de cimetières, des mines de chemin où l'on tue - et, à deux pas, des grognements d'inondation et des déchirements de tempête!' (p. I4). Uniquely here, rather than choosing to overlook the urban confusion or reduce it to neat stereotypes as he did during the black-face minstrel act, he acknowledges the impossibility of such an endeavour - and indeed, in this moment, Vallès conveys the complexity of all modern, 
urban existence, built on irresolvable contradictions and compromises: the text indicates then, obliquely, that France, like England, is too complex, class-divided, inconsistent and diverse to possibly have one, unified national character.

\section{Figs and strippers}

A prevalent French stereotype of English women, confirmed and strengthened by translations of Romantic poetry and Charles Dickens, was that they were modest by nature (or prudish, depending on one's perspective). However, in descriptions of London performance culture in French travel writing, there are as many if not more descriptions of female strippers than of English actresses and singers of more 'respectable' credentials. In representations of the debauched world of the strip show, the music accompanying the dancers is typically taken from a repertoire already particularly inflected with associations of 'Englishness' for the French reader, such as the jig. The jig, despite being a folk genre that had variants present in France as well as throughout Britain, is generally portrayed as the soundtrack to English life in the late nineteenth century, and it is presented by the French as the quintessential crystallization of English national character in music and dance. To some extent this draws upon the contemporaneous curiosity about folk music as the purest form of national music by theorists such as Julien Tiersot in his Notes d'ethnographie musicale; Bruno Nettl has remarked of this period that it was assumed that 'each people or culture has only one kind of music, one musical style, which really fits its personality'. ${ }^{28}$

In this respect, the presence of jig music in depictions of London's dens of iniquity has a powerful reality effect for French readers, persuading them that vice has just as intrinsic a relationship with the English character as these tunes do. However, in the case of the English, a long-standing tradition of mutual mockery in text and image means that even taking this anthropological interest in folk music into account, the public reception of the English jig would always be coloured by pre-existing popular clichés. Comedic café-concert characters representing awkward, frenetic, unseductive, buffoonish Englishmen and Englishwomen included jigs as a habitual part of their acts; it is probable that more French readers of travel writing would have been familiar with this type of performance than they were with treatises on English folk history. Indeed, of the twenty-eight café-concert songs I have found about comic English characters from the fin de siècle, fourteen begin with a jig in the introductory section before the performer has even taken up their singing position on the stage, and a further three include a jig motif at some point in the performance. It is with this context in mind that we should read the following examples from Hector France's Les Va-nu-pieds de Londres (1883) as he visits the nude theatres and dive bars of East London, and that we should consider his efforts to make serious criticisms of Englishness through the already ambivalent musical form of the jig.

In Les Va-nu-pieds, Hector France treats seedy songs and dances as a much more typical representation of Englishness as a whole than their marginal or, in some cases, outright illegal status might otherwise imply. The first instance of such 
lubricious entertainments is a description of a nude Tableaux Vivants show where, as the curtains opened 'au son d'une gigue légère jouée sur un piano invisible, les tableaux vivants se déroulaient', and the audience beheld '[des] exhibitions malsaines de femmes avachies, de crapuleux voyous et de filles à peine pubères'. ${ }^{29} \mathrm{He}$ then builds on this interconnection between the jig and sleaze with a visit to a private theatre in Whitechapel, where he and his companion buy gin for the child singers and dancers before the latter hurry backstage to get ready for their acts on the spit-and-sawdust stage. Before quoting at some length from this passage, it is worth highlighting that there would be nothing in this debauchery to strike the reader as essentially English were it not for the genre of the music; there were, after all, dancing girls aplenty and more female and child sexual exploitation in Paris than Hector France chooses to acknowledge here. ${ }^{30}$ After all, any French reader of novels or viewer of art, even those with no first-hand experience of the underside of Parisian nightlife, would be familiar with the figure of Zola's Nana in her state of undress, and of prostitutes and sexually-available dancers in images by artists such as Jean-Louis Forain and Constantin Guys. However, Hector France's repeated references to the jig music in his representations of these sordid venues indicate that his interest is in drawing conclusions not about sexual exploitation, but rather about the horrific English national character. First, 'cinq ou six jeunes drôlesses chantèrent [des] chansons graveleuses, firent les mêmes gestes immondes, suivis des mêmes gigues' (p. 298), and then the dance act - the main attraction - takes to the stage:

Triangle, piston et tambour entamèrent une marche militaire, et voici que défilèrent les demoiselles du corps de ballet. [...] Ran plan plan! Ran plan plan! Au pas, comme des soldats, elles traversèrent la scène, lentement, l'une derrière l'autre par rang de taille et sur un seul rang afin d'être bien vues, faisant bruyamment et en cadence retentir leurs talons sur les planches. Elles avaient la tête couverte d'un schall à la façon des madones ou des Irlandaises des jours de pluie. La pointe tombait jusqu'au-dessous de la croupe et, retenu devant par leurs mains croisées, le schall ne dépassait pas les hanches. Les jambes sans maillot montraient leurs blanches nudités. [...] Alors, retenant le schall de leurs deux mains comme si elles craignaient de laisser voir leur poitrine, elles commencèrent la gigue. Cette grotesque danse, caricature de l'art chorégraphique, sans laquelle il n'est pas de fête populaire, semble l'exacte expression du caractère national, raide, disgracieux, d'une lascivité hypocritement voilée.

Frénétiquement, avec des éclats de derviche en délire, l'orchestre accompagnait, et rien de plus étrange que ces filles la tête et le buste couverts, agitant par des mouvements épileptiques leurs jambes amaigries par la croissance, les nuits sans sommeil, la débauche hâtive, car la plus âgée comptait quinze ans à peine, et sur les vingt de la bande la moitié n'avait que douze ans. Mais le ballet eût paru monotone s'il eût duré longtemps ainsi; bientôt les schalls glissèrent à terre, et je compris le nom donné à cette érotique chorée, drawers' ballet, ballet des caleçons.

Entièrement nues jusqu'à la chaussure, elles ne portaient, pour cacher leur puberté naissante, qu'un caleçon de coton de baigneur, et dans le cynisme enfantin de leur vice, elles s'étaient ingéniées à lui faire tenir le moins de place possible, afin que le public ne perdît rien de leur nudité. Et toutes ces petites ribaudes, prises de rage, enfiévrées sous les regards ardents des mâles, continuèrent pendant quelques minutes, avec des gestes et un 
piétinement de convulsionnaires, cette danse digne du sabbat. Et empourprées, l'écume aux lèvres, l'œil perdu, ruisselantes de sueur, elles s'arrêtèrent haletantes, reprirent leurs schalls, s'en enveloppèrent et, s'élançant de la scène, se répandirent dans la salle, tandis que l'orchestre continuait ses airs de gigue endiablée. (pp. 300-OI)

Throughout, France emphasizes the jig's inherently English nature, both as a genre in general and in terms of this performance in particular. We are told that no popular festival in England is possible without it (although France attends no popular festivals in the course of this book), and that it is the exact expression of national character. So inherent is the jig to Englishness that the frenetic music even seems to trigger an instinctive response in the girls' bodies. France orders his description carefully in order to convey this idea: first, the delirious music strikes up, and shortly afterwards the girls begin to dance like 'épileptiques' and 'convulsionnaires', as though the madness of the music triggers the madness of their physical movement. Then, at the end of the piece, the diabolical music does not stop, and thus nor do the girls: instead of retreating backstage as we might expect, the 'airs de gigue endiablée' continue and they seem to force the girls to keep dancing, as they skip off into the audience to find transient sexual customers.

Understand the jig, France contends, and you understand the nation. Whilst this genre might once have been the dance music of innocent peasants, France presents an image of a degraded nineteenth-century jig that, like the English nation as a whole, he implies, has fallen from its pastoral roots and entered a period of decline and decadence. Indeed, it is clear that Hector France ascribes a considerable significatory power to music, as he composes a text that endeavours to make an aural as well as a visual impact upon the reader. We are informed of the precise instruments in the small ensemble so we can imagine the tonality; we are not only told that the drums were playing, but are given an explicit rendering of their ran-plan-plan; we not only see the girls march but are given to hear their heels pounding on the boards; and the jig music accompanies the girls' every move, punctuating the narrative, so that the two are rendered inextricable. Both march and jig were familiar musical genres to the fin-de-siècle French audience, who would have been able to imagine how the transition would sound between the straight rhythms of the march as the girls entered the stage (often strings of quavers in a 2/4 time signature) and the tertiary rhythms of the jig (typically triple sets of quavers in a compound time signature). By placing the music that accompanies this dance in both the first line of text and the last, France implies that this national musical genre is also a musical metaphor for all the other manifestations of vice that he indicates therein, and the strangeness of the aural experience that he depicts in the text impresses upon the reader how remote all of this is from French culture.

Within this framework, France makes the image of immorality as shocking as possible: the long, detailed description makes uncomfortable reading, with its clear sexual exploitation of children and its projection of vice away from the adult viewer and onto the child performers; it is the 'hussies' who are debauched, he says, who want to show off as much as possible of their nudity, and who desire to enflame the 
ardent eyes of their male audience rather than performing simply out of economic necessity. Les Va-nu-pieds de Londres presents itself in its preface as a text written in sympathy for the poor, and so the reader initially approaches this description expecting to be presented with an object of pity; yet in the presence of the 'gigue endiablée', a cognitive dissonance makes itself felt. First, there is dissonance because the promise of pity appears under France's pen as scorn; it transpires that the critique is not primarily to promote reform in England, but to elevate the self-esteem of the French reader by comparison - an appealing idea, at a time of fear about degenerating national morality, of low birth rates and of rampant syphilis. As Britain grew in wealth and political strength in the colonial race, to explain such lewdness not merely as immorality but as inherent to English nature and culture, rooted even in their music and dance, suggests that the English are on the brink of decadence, and in the long run they might not be victorious in the Darwinian survival of the fittest after all. Secondly - and more strikingly - dissonance emerges because the reader's ability to assimilate Hector France's deeply negative image of English character is undermined by the laughter triggered by the presence of the jig throughout these erotic revelries. Whilst the jig certainly does connote Englishness, and it does seem bizarre and somewhat perverse to find it in these contexts, it also brings to mind the funny accents, hilarious dancing, frumpy tweed and outrageous stick-on mutton chops of the cafés-concerts. The reader inevitably struggles, therefore, to take seriously the seriousness that France seems to espouse.

The lowest echelon of Hector France's voyage of discovery through the strip joints of East London takes him to a tavern in Whitechapel. Here, although without the same implications of child sexual exploitation, France treats the reader to another long, detailed rendition of the music he hears, the dance he watches and nicknames 'Eve's Jig', and the sight of the gradual removal of the dancer's clothes:

Tout à coup, faisant signe au violoneux, elle monta sur la table du milieu en s'aidant de l'épaule d'un jeune drôle à mine de furet, et le violon ayant entamé l'air Speed the Plough, le gigue commença. Les mouvements furent lents d'abord, puis se se [sic] précipitèrent; la fille s'anima, frappant du talon à crever la table, et le musicien ayant accéléré la mesure, elle sembla bientôt prise d'une folie hystérique. Alors se passa une scène étrange: le vieux jeu du clown, dans les cirques forains, lorsque vêtu en campagnard il se hisse sur un cheval, et, se dépouillant peu à peu de toutes ses hardes, paraît, aux yeux émerveillés, dans son maillot éclatant de paillettes. [...]

[here there is a detailed account of each piece of clothing as it falls]

La danseuse en chemise, ou plutôt en peignoir, continua une gigue folle au milieu des applaudissements des spectateurs. Et, souriante, le front calme, confiante, son chapeau de velours transformé en aumônière, elle fit lentement le tour de la société. [...] Elle remonta sur la table. Alors, avec une pudeur que je n'attendais guère, elle baissa, sourde aux protestations de l'assemblée, l'unique flamme de gaz, et quand il ne resta plus qu'une petite lumière tremblotante, son peignoir glissa. [...] Les fureurs des mâles en rut éclataient dans les profondeurs intimes de ces gueux. (pp. 79-80)

Again, France places significance on the aural as well as the visual image of the scene; he elaborates upon the type of instrument, the name of the tune, the 
progressive accelerando of the fiddle-player's rhythm, and the dancer's heel stomping on the table.

The problematization of this episode goes further here due to errors in the identification of the music. First, the folk tune Speed the Plough is not a jig at all but a reel, which has a $4 / 4$ time signature and thus does not easily accommodate the compound rhythms of the jig; the dance steps that result from this are thus likely to be very different, even if the primary focus is on striptease rather than authentic folkdance. Thus, despite France's emphatic assertions that the jig is the lifeblood of English culture and the mirror of its national spirit, he is clearly not sufficiently familiar with its features to distinguish it from other musical or dance forms. Logically, therefore, he may also not be able to distinguish between features that are 'typically English' and those pertaining to other social or national groups. Furthermore, the name Speed the Plough recalls a play of the same name published in I798 by Thomas Morton, in which the infamous 'Mrs Grundy' is first known to have featured, the priggish worshipper of convention who inspired the neologism 'grundyism' that subsequently appeared as a figure of speech across Western literary traditions. It was a common criticism of England by the French that the English only claim to be upstanding, and that they loudly condemn the immorality of others (especially the Parisians) but that they hypocritically practise just the same immorality, or even worse, behind closed doors. Perhaps Hector France is drawing this connection for his reader by mentioning this folksong even though it cannot have been the musical form to which the woman was dancing, if she was indeed dancing a jig. In doing so, the text comes to contain a subtle reference to this archetypal figure of English hypocrisy and conventionality in the most salacious of contexts. Indeed, a copy of the text held by the British Library is annotated by an unknown hand with several exclamations of 'menteur!', 'blagueur!', 'cornichon!', and 'je voudrais connaître le menteur qui écrit de telles choses sur mes compatriotes', suggesting that perhaps Hector France's slight found a Mrs or Mr Grundy in the Reading Room.

At first glance, this seems to suggest that Hector France's criticism has hit homeyet the 'Englishness' of this hypocrisy is called into question by his choice of an extremely negative lexicon to condemn the spectacle. More often than not, his rhetoric implies that his disgust is primarily an aesthetic one: those 'femmes avachies', the surroundings in the theatre where the wallpaper peels like a leper's skin, the fact that he is forced to confront the 'détails ignobles, les côtés écœurants et immondes' (p. 295), and the crazed 'mouvements épileptiques' that are far from a smooth, seductive burlesque dance. France's text indicates that his main irritation is that the English sex industry feels ugly and dirty from an aesthetic point of view, rather than because he dislikes the sexual objectification or exploitation of women and children per se - yet, as Stallybrass and White have argued in their discussion of lowbrow culture, 'disgust always bears the imprint of desire. These low domains, apparently expelled as 'Other', return as the object of [...] longing and fascination. ${ }^{31}$ Thus, whilst lambasting the English for their moral hypocrisy on the one hand, at the same time he demonstrates the very same hypocrisy himself: he does, after all, pay the entrance fee and facilitate the industry; he attends strip joints on at least three 
separate occasions; he gives his fascinated attention to the sexualized bodies of the girls on stage; he increases the audience to these performances by sharing every detail with his readers; and he never actively condemns the theatrical managers who hire child performers, who sexually exploit impoverished women, or who provide venues for lewd acts. Thus, at the same time as he tries to convince the audience of the ingrained association between English national character and moral hypocrisy by way of these erotic jigs, he exhibits those supposedly English characteristics himself; he demonstrates that national character is fluid at the very moment that he seeks to demonstrate its exclusiveness.

The last problematic aspect of the anecdote of 'Eve's Jig' that I shall discuss here can be found in the emphasis placed on the arousal experienced by the audience. Though it can be assumed that the audience at the 'Tableaux vivants' and the 'Drawers' Ballet' were aroused by the performances too, this is not described in the text. In the tavern, however, the French reader can witness the Englishmen as they are enflamed by the visual fantasies of striptease and by the aural affect of the fevered music. Barthes remarks in his writing on striptease that the gradual exhibition of flesh conceals rather than reveals the true locus of desire and thus leaves a lingering dissatisfaction that serves to keep desire circulating: 'le nu qui suit reste lui-même irréel, lisse et fermé comme un bel objet glissant, retiré par son extravagance même de l'usage humain. ${ }^{32}$ Furthermore, Barthes contends that the dance aspect of striptease, 'faite de gestes rituels, vus mille fois [...], cache la nudité, enfouit le spectacle sous un glacis de gestes inutiles' ${ }^{33}$ Hector France's tavern stripteaser performs ritualized gestures in the form of the jig, and thus the spectacle of her nakedness is hidden to some extent behind these gestures, resisting the French reader's desiring gaze. Indeed, the jigging stripper or the dancing girls of the 'Drawers' Ballet' are still more resistant than the French burlesque dancer, using as they do gestures that have been ritualized not only within the world of dance, but also by French comic singers and by decades of French travel writing about the English. Corinne Perrin has rightly remarked that the idea of 'the English' was recognizable not through its relatedness to a referential reality, but 'par référence à d'autres Anglais de papier, [...] des représentations collectives'; 34 whilst Hector France has these girls remove their clothes, the presence of the heavily-stereotyped jig veils them under layers of paper, and the mystery of Englishness evades France's text rather than being contained in the categorical judgements he proclaims.

\section{$* * * *$}

At first glance, music across the Channel provides fertile terrain for creating a hierarchy of superior Frenchness vis-à-vis inferior Englishness to assist in addressing wider concerns of French national identity, patriotism, political rivalry, modernity and racialized prejudices, in an era of damaged national pride following $1870-\mathrm{I} 87 \mathrm{I}$; of unstable national identity faced with internal conflicts such as the constitutional crisis of May 1877, Boulangism, anarchism and the Dreyfus Affair; and of mounting rivalry between France and Britain in the colonial sphere. However, on closer 
examination, rather than music revealing an 'authenticity effect' that, according to James Buzzard, provides 'the epiphanic moment in which the unified essence of the place shines forth', efforts to bring English musical culture to bear on conceptualizing 'English nature' are problematic and so the epiphanic moment never materializes. ${ }^{35}$ The complexity of the realities of English social structures and of modernity, the greater familiarity of the English for the French in comparison to distant Oriental nations, and the multifaceted idea of 'Frenchness' to which such writers try to respond, all ultimately reveal the problematic nature of trying to make the individual aspects of any culture signify for an overarching national character.

\section{School of Cultures, Languages and Area Studies \\ University Park \\ University of Nottingham $\mathcal{N} G 7{ }_{2} R D$ \\ United Kingdom \\ hannah.scott@cantab.net}

\footnotetext{
NOTES

1 François-Joseph Fétis, 'Essai sur la musique en Angleterre', Revue des Deux Mondes, 3 (I833), I29-70 (p. I30).

2 Le Comte L. Lafond, L'Écosse jadis et aujourd'hui, études et souvenirs (Paris: Calmann Lévy, I887), p. 3; Edmond de Goncourt, La Faustin (Paris: Charpentier, I882), p. 302.

3 These volumes refer to a plethora of Frenchmen (Berlioz, Ambroise Thomas, Gounod, Lalo, Saint-Saëns, Bizet, Reyer, Massenet, Debussy, d'Indy, Chabrier, Erlanger, Charpentier, Boieldieu, Méhul, Lamoureux), Italians (Verdi, Rossini, Puccini), Germans (Wagner, Brahms, Schumann, Gluck, Mozart, Beethoven, Richard Strauss), one Belgian (César Franck), and a Slovenian (Hugo Wolf) - but not a single English composer. See Adolphe Jullien, Musiciens d'aujourd'hui (Paris: Librairie de l'art, I892); Romain Rolland, Musiciens d'aujourd'hui (Paris: Hachette, I9o8); Alfred Bruneau, Musiques d'hier et de demain (Paris: Charpentier, I9oo).

4 Louis Fourcaud, 'Musique', Le Gaulois, 9 June r889, p. 2.

5 Jann Pasler, 'Theorizing Race in Nineteenth-Century France: Music as Emblem of Identity', Music Quarterly, 89 (2008), 459-504 (pp. 462, 490).

6 The long history of cross-Channel exchange and its influences on their nineteenth-century relations have been usefully discussed in studies including: Robert and Isabelle Tombs, That Sweet Enemy: The History of a Love-Hate Relationship (London: Random House, 2006); Sylvie Aprile and Fabrice Bensimon (eds), La France et l'Angleterre au dix-neuvième siècle (Paris: Créaphis, 2006); and Andrew Radford and Victoria Reid (eds), Franco-British Cultural Exchanges, I880-1940 (Basingstoke: Palgrave Macmillan, 2012).

7 Jane Fulcher, French Cultural Politics and Music: From the Dreyfus Affair to the First World War (Oxford and New York: Oxford University Press, I999), p. 225.

8 Ruth Rosenberg, 'Among Compatriots and Savages: The Music of France's Lost Empire', Music Quarterly, 95 (2011), 36-70.

9 Darwin, The Descent of Man, and Selection in Relation to Sex, $2^{\text {nd }}$ edn (London: John Murray, I882), pp. 566-74.

10 Pamela Potter, 'The Concept of Race in German Musical Discourse', in Julie Brown (ed.), Western Music and Race (Cambridge: Cambridge University Press, 2007), pp. 49-62 (p. 5o); Annegret Fauser, Musical Encounters at the I889 Paris World's Fair (Rochester, NY: University of Rochester Press, 2005).
} 
11 Pasler, 'Theorizing Race', p. 463.

12 Among a plethora of works, see: Charles Valframbert's study of political structures in Régime municipal et institutions locales de l'Angleterre, de l'Écosse et de l'Irlande (Paris: Marescq aîné, I873); Jules Simon's attention to the English education system in La Réforme de l'enseignement secondaire (Paris: Hachette, I874); Pierre de Coubertin's numerous studies on education and sporting life, including L'Éducation en Angleterre (Paris: Hachette, 1888) and L'Éducation anglaise en France (Paris: Hachette, 1889); and Maurice Courant's positive assessment of British education and colonialism in Études sur l'education et la colonisation (Paris: Librairie générale de droit et de jurisprudence, 1904).

13 H. Moreno, Le Ménéstrel, io March 1872 to 30 June I872.

14 Ibid., 30 June 1872, p. 253.

15 The struggle over high- and low-brow culture within France has been discussed by Pasler, who explores the concerns of the ruling elites regarding the popularity of the cafes-concerts: Jann Pasler, Composing the Citizen: Music as Public Utility in Third Republic France (Berkeley, CA: University of California Press, 2009); Lawrence Levine traces similar debates occurring in the United States as elites sought to elevate the artistic taste of the lower classes, and in doing so drew ever-stronger lines between art music (opera, symphony etc.) and popular music: L. Levine, Highbrow/Lowbrow: The Emergence of Cultural Hierarchy in America (Cambridge, MA: Harvard University Press, 2009).

16 Jules Vallès, La Rue à Londres (Paris: Charpentier, 1884), p. 37; page references to this text will be given henceforth in parentheses in the body of the article. Max O'Rell, L'Ami Macdonald: Souvenirs anecdotiques de l'Écosse (Paris: Calmann Lévy, I887), p. II.

17 The fact that the minstrelsy tradition of mimicking and mocking dark-skinned people is inherently racist was not recognized by the nineteenth-century European mind, and consequently for the purposes of the present study I will leave this aspect aside and direct the reader to the fruitful discussions elsewhere, including: Annemarie Bean and James V. Hatch (eds), Inside the Minstrel Mask: Readings in Nineteenth-Century Blackface Minstrelsy (Hanover, NH: Wesleyan University Press, 1996); Dale Cockrell, Demons of Disorder: Early Blackface Minstrels and their World (Cambridge: Cambridge University Press, 1997); and, on the late-Victorian tradition specifically, Michael Pickering, 'John Bull in Blackface', Popular Music, I6.2 (I997), I8I-202.

18 A growing body of scholarship has begun exploring this link between urban noise and modernity, including with reference to Paris: Aimée Boutin, City of Noise: Sound in Nineteenth-Century Paris (Urbana: University of Illinois Press, 2015); to the London of Virginia Woolf: e.g. Kate Flint, 'Sounds of the City: Virginia Woolf and Modern Noise', in Literature, Science, Psychoanalysis, I830-1970, ed. by Helen Small and Trudi Tate (Oxford: Oxford University Press, 2003), pp. I8I-94, and Angela Frattarola, 'Developing an Ear for the Modernist Novel: Virginia Woolf, Dorothy Richardson and James Joyce', Fournal of Modern Literature, 33.I (2009), I32-53; and to the Futurists' vision of noise music: e.g. Robert P. Morgan, 'A New Musical Reality: Futurism, Modernism, and "The Art of Noises"', Modernism/Modernity, I.3 (I994), I29-5I.

19 Félix Narjoux, En Angleterre: Angleterre-Écosse (Les Orcades, Les Hébrides), Irlande; Le Pays, Les Habitants, La Vie intérieure (Paris: E. Plon, Nourrit et Cie, I886), p. 69.

20 Marie Anne de Bovet, Trois mois en Irlande (Paris: Hachette, I908), p. 9 I.

21 Brecht on Theatre, trans. and ed. by John Willett (London: Methuen, I964), p. 89.

22 Michael Pickering, 'White Skin, Black Masks: "Nigger" Minstrelsy in Victorian England', in Music Hall: Performance and Style, ed. by J. S. Bratton (Milton Keynes and Philadelphia: Open University Press, I986), pp. 70-9I (p. 84).

23 See, for example, A. Templar's poem 'Infant Slavery, or the Children of the Mines and Factories' (I840), and Elizabeth Gaskell's Mary Barton (1848), where Barton cries that 'we're their slaves as long as we can work; we pile up their fortunes with the sweat of our brows' (Mary Barton (London: Penguin Books, 1994), p. 8). This was still common currency when Robert Tressell published his controversial Ragged Trousered Philanthropists in 19I4, and the socialist Owen explains that 'instead of enjoying the advantages of civilisation we are really worse off than slaves, for if we were slaves our owners, in their own interest, would see to it that we always had food' (London: Wordsworth Editions, 2012), p. 5I.

24 Engels, Principles of Communism, trans. by Paul M. Sweezy (New York: Monthly Review, I952), pp. 7-8. 
25 This is discussed in compelling detail in Fulcher, French Cultural Politics, and Pasler, Composing the Citizen. It also becomes a significant and powerful part of fascist political movements in the twentieth century. See: Peter Tregear, 'Sounding Fascism: T. W. Adorno and the Political Susceptibility of Music', Culture, Theory and Critique, 42.I (I999), 36-48 (p. 46); Ron Eyerman and Andrew Jamison, Music and Social Movements: Mobilizing Traditions in the Twentieth Century (Cambridge: Cambridge University Press, I998); Carolyn Birdsall, Nazi-Soundscapes: Sound, Technology and Urban Space in Germany, 1933-1945 (Amsterdam: Amsterdam University Press, 2012).

26 Vallès decries the working-class Englishman as someone who 'se pressera alors, au nom de la servilité nationale qui court lécher le pied des hiérarchies' (p. Io), without taking into account the frequent and often bloody working-class uprisings, protests and strikes throughout the nineteenth century, such as Peterloo (I8I9), the Cato Street Conspiracy (1820), the Reform Riots (I83I), the Preston Strike (I842), the Sunday Trading Riots (I855), and the Reform League Hyde Park Demonstration (I866).

27 This underlying complexity is discussed by Edward Said in Orientalism (New York: Pantheon Books, I978); Tim Youngs (ed.), Travel Writing in the Nineteenth Century (London and New York: Anthem Press, 2006); David Scott, Semiologies of Travel: From Gautier to Baudrillard (Cambridge: Cambridge University Press, 2004); and Benedict Anderson, Imagined Communities: Reflections on the Origins and Spread of Nationalism (London and New York: Verso, I99I).

28 Bruno Nettl, Folk and Traditional Music of the Western Continents (Englewood Cliffs, NJ: Prentice-Hall, 1965), p. 9. This is discussed in more detail in studies including those by Pasler ('Theorizing Race'), and Rosenberg (Music, Travel, and Imperial Encounter in Nineteenth-Century France: Musical Apprehensions (London and New York: Routledge, 2015)). See also, on Fétis's role in the development of music history including folk music, Katharine Ellis, Music Criticism in Nineteenth-Century France (Cambridge: Cambridge University Press, I995), pp. 33-45.

29 Hector France, Les Va-nu-pieds de Londres (Paris: Charpentier, I883), pp. 287, 289. Page references to this text will be given in paratheses in the body of the article.

30 Novelist and essayist Gabriel Mouray remarks in the preface to his travel diaries from the United Kingdom that: 'Je sais l'argument en vogue: scandales inoubliés de la Pall Mall Gazette, hypocrisie britannique, etc. [...] Mais ceci est d'ordre privé, et la prostitution secrète de France n'a rien à envier [...] à celle d'Outre-Manche' (Passé le détroit (Paris: Ollendorff, I895), p. 69). Even in the French translation and commentary on William Stead's Pall Mall Gazette scandal, chapters II and I2 are dedicated to the sale of underage girls by French parents and pimps to English sex traffickers this is intended to reflect the dangers of English depravity for France, but it no less shows that there were those within France prepared to make an income from selling young girls into sex slavery: Les Scandales de Londres, dévoilés par la Pall Mall Gazette (Paris: E. Dentu, I885), Part III.

31 Peter Stallybrass and Allon White, The Politics and Poetics of Transgression (London: Methuen, I986), p. I9I.

32 Roland Barthes, Mythologies (Paris: Seuil, I957), p. I39.

33 Ibid., p. I40.

34 Corinne Perrin, 'Anglais en papier: le cliché et le miroir', in Antoine Court and Pierre Charreton (eds), Regards populaires sur l'Anglo-Saxon: Drôles de types (Saint-Étienne: Publications de l'Université de Saint-Étienne, 2003), pp. 9-29 (p. Io).

35 James Buzzard, The Beaten Track: European Tourism, Literature, and the Ways to 'Culture', I8ooI9I8 (Oxford: Clarendon Press, I993), p. I88. 